\title{
Tampereen elokuinen erikoinen
}

Tampereen yliopiston täydennyskoulutuskeskus on jo monena vuonna pannut toimeen aikuiskoulutussymposion elokuun jälkipuoliskolla. Tänä vuonna tilaisuus oli 21.-22.8., ja sen teemana oli Aikuiskoulutuksen tutkinnot ja legitimaatio.

Ennakkoilmoittelussa järjestäjä lähestyi valitsemaansa aihetta varsin räväkästi. Ärsykkeeksi heitettiin mm. seuraavia kysymyksiä: ' Estävätkö rakenteet ja asenteet joustavien aikuistutkintojen muodostamista?" - "Onko suomalainen koulutuspolitiikka tehnyt diplomitaudista tarttuvan?" - "Koulutuksen legitimaatio - sivistyksen kastraatio?" — "'Sertifikaatti — työllisten valtakunnan avain?",

Englannilla oli ensimmäisen päivän ohjelmassa vallitseva asema. Tämä johtui siitä, että vierailevaksi luennoitsijaksi oli kutsuttu tunnettu aikuiskasvatuksen professori Peter Jarvis (University of Surrey). Hänen esityksensä todistusjärjestelmästä ja byrokraattisesta valtiosta oli mielenkiintoinen ja sinänsä hyvä. Kun sen argumentaatio ymmärrettävistä syistä perustui valtaosaltaan englantilaisiin lähtökohtiin, liitynnät ja relevanssi suomalaista todellisuutta ajatellen olivat niukat. Audioyhteytenä Englantiin toteutetusta tutkintomallin sovelluksesta voi sanoa samaa. Jarviksen toinen, elinikäistä oppimista käsitellyt luento jatkoi samaa linjaa: mielenkiintoinen, mutta käyttöarvo oli enemmän yleissivistävä kuin käytännöllinen.
Symposion parasta antia oli KT h.c. Erkki Ahon puheenvuoro "Tarvitaanko Suomessa uudenmuotoisia, joustavia aikuiskoulutustutkintoja?" Samaa aihepiiriä käsitteli viisi muuta puhujaa. Epäilemättä se, mistä itse kukin eniten piti, riippui paljolti siitä, mitä aikuiskoulutuksen sektoria asianomainen edusti. Subjektiivisen arvioni mukaan Juha Sihvosen "Sidottu koulutus vapaassa sivistystyössä" oli niin antoisa, että olen esittänyt sen julkaisemista tässä lehdessä, mikä myöhemmin toteutuneekin.

Päätöspuheenvuoroksi oli sıortettu Lauri Mehtosen alustus "'Tieteellisyys ja aikuisuus'. Ainakin Mehtosta mielellään kuuntelee. Hänen toteamuksensa siitä, että hän puhuu aina samat asiat, ei tosin pitänyt paikkaansa. Hänen Kanttulkintansa kuulin kyllä kolmatta kertaa (kerta kerralta sanoma paranee), mutta antiikissa en ole ennen Mehtosen seurassa vaellellutkaan. Kun se nyt tapahtui, opas oli hyvä ja vastaan tulleissa henkilöissä oli jotakin tuttua.

Voi olla niin, että tutkinto- ja legitimaatiosysteemi on siinä määrin vielä Suomessa hajanainen ja kehittelynalainen asia, että siitä ei voi kovin solidia koulutustilaisuutta järjestääkään. Symposio tarjosi kuitenkin verraten monipuolisen läpileikkauksen siihen, missä mennään, mitä suunnitellaan. Muu anti onkin sitten jo pitkälti osanottajista itsestään kiinni: ajatusta kirvoittavia esitykset olivat silloinkin, kun ne eivät suoranaisesti liittyneet kotimaiseen arkeen. 